Society for the Anthropology of Work • Essential Labor

\title{
Essentially Disposable
}

Scott Timcke, Shelene Gomes

Published on: Nov 02, 2020

DOI: $10.21428 / 1 \mathrm{~d} 6 \mathrm{be} 30 \mathrm{e} . \mathrm{f} 3 \mathrm{~d} 5 \mathrm{cda} 3$

License: Creative Commons Attribution 4.0 International License (CC-BY 4.0). 
We live in a culture in which the threshold for a person's disposability is exceedingly low. But to acknowledge this reality is to breach a taboo. For the idealism behind a universal human rights culture, however unevenly it is lived, rests upon a belief that the fundamental worth of a person must be sacrosanct if democracies are to flourish. Yet everyday life under neoliberalism demonstrates the opposite: for many people, their labor power is depleted until exhaustion and then they are discarded without a second thought. Here, the neoliberal mantra-one's final station is a meritocratic grading and thus fair, just, and appropriate-is revealed for what it is, a justification for the reproduction of suffering. As Clive Y. Thomas (1988) wrote in the Caribbean context, being poor and powerless are often synonymous. During this global coronavirus pandemic, Thomas's remarks foreground how the interconnections of structural advantage and disadvantage bear on human vulnerability.

Writing from Trinidad and Tobago, we aim to think through the conditions of disposable workers on the margins of this Caribbean society. We focus on two subgroups of workers, people doing care work and street work. Both kinds of work are undervalued and poorly remunerated. Care workers include professionals like doctors and nurses, but also grocers and uncredentialed caregivers for the elderly. Street workers include sanitation workers and even gardeners.

While Trinidad and Tobago was in hard lockdown from March to May 2020, essential workers were nevertheless expected at their job sites. Ordinarily these workers are taken for granted and not given their due, but with the onset of lockdown they were quickly essentialized. This labeling was one component of a discursive transformation that positioned them as subjects willing to do the dirty work to keep the rest of "us" safe. Hardy and capable of adapting to the many unknown variables of a global pandemic, they became tokens of the nation, embodying the watchwords associated with the country's first prime minister, Eric Williams: discipline, production, tolerance.

The term essential worker can be both ascribed and prescribed. With it, through conditions not of the worker's making, bosses have the authority to compel persons to work notwithstanding the intense risks that come from working with the public, especially when so little is known even now about the virus's precise characteristics. Essential workers need active hands and minds; their bodies bear the vulnerability that comes from being evicted if they cannot afford to pay rent or service a mortgage. These workers need to weigh the risks that come from unemployment in an economic contraction against the risks of contracting the coronavirus. Such fears make essential 
workers controllable and bring them back to the workplace, day in and day out. Workers know that they are disposable, and this keeps them clocking in for shifts in which their disposability is all too apparent. Effectively, essential workers are coerced labor.

\section{Some Taboos of Neoliberalism}

There is value, we suggest, in thinking about the ascribed and prescribed attributes of the essential worker. In his essay "Taboo and the Ambivalence of Emotions," Sigmund Freud (2009: 26) explains how taboo has two referent meanings. Drawn from a Polynesian word, the term connotes things that are "sacred, consecrated" but also "uncanny, dangerous, forbidden and unclean." ${ }^{1}$ Its opposite in Polynesia was noa, which referred to the plainness of things, "something ordinary and generally accessible." One view taken by social scientists is that such prohibitions tend not to be products of normative reasoning, but instead guard against transgressions against powerful unseen forces. In this conception taboo is like a "contagion" (Freud 2009: 31), where social station does not automatically grant the offender immunity.

With COVID-19, we can see how emerging struggles around civility involve similar rituals of handling and coming into contact with things unseen. Violating these prohibitions by not wearing a mask or washing one's hands can make a person taboo and require them to undertake ceremonies of purification before being permitted to rejoin others. But in his essay, Freud (2009: 37) disagrees with this commonplace explanation, arguing instead that taboos and compulsions are linked as different presentations of a deeper "unconquerable anxiety." He relays how certain of his patients spoke of their compulsions in terms of "the vague premonition that a person [in] their environment will suffer harm if they should violate the prohibition."

While we disagree with Freud's (2009: 38) explanation for what he calls the "touching phobia," we do think there is value in reframing ambivalent behavior-characterized in terms of conflict between the unconscious and conscious-as a kind of neurosis cultivated by capitalist social relations. Consider the aversion to touch in light of the many unknowns about coronavirus. "Don't touch your face, eyes, mouth," the advice goes, "you don't know who you have come into contact with." For essential workers in Trinidad and Tobago, there were ambivalent choices around weighing risks that led to profound anxiety. Just as taboos and compulsions are manifestations of a deeper cause, we suggest that the plight of the essential worker is a manifestation of neoliberalism's unresolved contradictions. The unconscious compulsion to continue exploiting workers, paired with a conscious taboo against questioning this course of action, form 
an easy rationalization to essentially dispose of workers if circumstances call for it. These behaviors reveal not only anxiety about falling profits, but also a foggy naturalization of social relations that come to be accepted as such.

\section{The Magical Beliefs of Capitalism}

Given the suddenness of the onset of the coronavirus and the initial equivocation of the public health response in many places, Mary Douglas's (2001) line of argument from Purity and Danger is also apt. In this text, Douglas writes about how societies treat anomalous events and the ambiguity they bring. Analyzing practices of ritual cleanliness, Douglas (2001: 1) attributes fear in modernity to "beliefs in horrible disasters which overtake those who inadvertently cross some forbidden line of developing some impure condition." She goes on to make it clear that "some pollutions are used as analogies for expressing a general view of the social order" (Douglas 2001: 3). Here, Douglas draws our attention to the status of the contagious through associated rituals of separation and demarcation.

The need to wear a mask, wash hands, and avoid close proximity to others is sound epidemiological advice in the current moment, but these mandates can also be thought of as a pollution belief with considerable symbolic value for a public not well versed in epidemiology. For the telecommuting class, they encode worries about encountering essential workers who could have transgressed by not following protocols. Thus, every encounter courts catastrophe. In the housing compound where we live, conversations with neighbors have revealed that many see each potential transgression potentially upending the present order. Yet this order is itself symbolically threatened if, for instance, the compound's garden has not been attended to. Here, the essential worker is deemed both a possible vector of trouble and the key to staving off trouble of a different sort. Thus, essential workers were to be separated, their movements adjacent to "us" in the compound. They were under strict instructions by management to do no more than needed and to avoid lingering where residents gather. As Douglas (2001: 164) concluded, "the quest for purity creates problems and some curious solutions." Certainly, this much was clear in our own yard.

\section{Democratizing the Caribbean}

Thankfully, by summer's end, community spread of the coronavirus had been somewhat contained in Trinidad and Tobago. But this did not mean that care and street workers did not face considerable uncertainties. Esteem for their work may have been suddenly elevated, but their wages stayed the same or in fact decreased with 
staggered work hours. In this context, the term essential worker denotes those who do not take part in the constitution of social order, who are excluded from making the rules to which they are subject. Counter to invocations of unity in collective life, the treatment of essential workers in Trinidad and Tobago points to disunity and fragmentation as seen in very different experiences of the pandemic. Whereas some can work from a sanctuary, others are compelled by economic forces to forego their safety and risk the safety of their loved ones. Yet to frame things in these terms is to breach mores that pretend private compulsion is a public service.

As twentieth-century social theory showed, taboos can function as a means for those with authority to protect themselves. But whereas Mary Douglas (2001: 166) wrote of how "ritual mixing up and composting of polluting things" could give rise to a more complete belief system, the hard separations that we have mentioned resulted in partiality and incompleteness. The peculiarities of neoliberal capitalism's magical beliefs led to a limited comprehension of the social effects of coronavirus, undermining the solidarity that would have been required to address it head on. As it stands, the vulnerability that we have described is facilitated by the antinomy of essential workers being both disposable and necessary in our current economic formation. A vibrant world of democracy is in the end incompatible with social relations where the poor, to return to Clive Thomas's formulation, have been made powerless.

\section{Note}

1. To be clear, we do not think there is any merit to Freud's conceptualization of sexual relations in primitive culture, or to his theorization of their repression in modernity. While we draw on a selection of his ideas to think through discourses of legitimation for social reproduction, this does not mean that we seek to cast Trinidad and Tobago as a primitive culture.

\section{Author Bios}

Scott Timcke is a comparative historical sociologist affiliated with the Cátedra de Estudios del Caribe Norman Girvan, La Habana in Cuba, who studies issues of race, class, technology, and social inequality. His approach to these topics has been shaped by South African and Caribbean critiques of the Anglo-American liberal tradition. His second book, Algorithms and the End of Politics: How Technology Shapes Twenty-FirstCentury American Life is forthcoming with Bristol University Press.

Shelene Gomes is a sociocultural anthropologist at the University of the West Indies in Trinidad and Tobago. She has carried out ethnographic fieldwork in East Africa, 
tracing the linkages between cosmopolitan imaginings and the Caribbean. Among other venues, her work has appeared in African and Black Diaspora: An International Journal, The Global South, Social Anthropology, and Virtual Brazilian Anthropology.

\section{Preview Image}

Courtesy of Gilbert Mercier.

\section{References}

Douglas, Mary. 2001. Purity and Danger. New York: Routledge. Originally published in 1966.

Freud, Sigmund. 2009. Totem and Taboo. New York: Cosimo Classics. Originally published in 1913.

Thomas, Clive Y. 1988. The Poor and the Powerless: Economic Policy and Change in the Caribbean. New York: Monthly Review Press. 